\title{
Determinant factors of external audit opinion modification in Portuguese municipalities
}

\author{
Isabel Maldonado \\ GOVCOPP - Universidade de \\ Aveiro \\ REMIT - Universidade \\ Portucalense \\ Porto, Portugal \\ ianm@uportu.pt
}

\author{
Carlos Pinho \\ GOVCOPP - Universidade de \\ Aveiro \\ Aveiro, Portugal \\ cpinho@ua.pt
}

\author{
Carla Azevedo Lobo \\ REMITand IJP - Universidade \\ Portucalense \\ Porto, Portugal \\ cadsa@uportu.pt
}

\begin{abstract}
This paper aims to identify the determinant factors of external audit opinion modification in Portuguese municipalities that integrate the metropolitan areas of Porto and Lisbon, covering 65 municipalities. The defined time horizon was from 2013 to 2017. The analysis allows to identify six predominant factors related with: non-current assets, amortizations, investment subsidies, debts to receive, equity investments and provisions as reasons to modified opinions. The study also highlights the fact that approximately one-third of modified opinions are related to the identification, classification, measurement and assets registration.
\end{abstract}

Keywords - auditing, municipalities, modified opinion.

\section{INTRODUCTION}

Being the purpose of an audit to enhance the degree of confidence of intended users in the financial statements, according to [1] "this is achieved by the expression of an opinion by the auditor on whether the financial statements are prepared, in all material respects, in accordance with an applicable financial reporting framework. In the case of most generalpurpose frameworks, that opinion is on whether the financial statements are presented fairly, in all material respects, or give a true and fair view in accordance with the framework.".

The auditor opinion can be classified as Unmodified opinion when the auditor concludes that the financial statements are prepared, in all material respects, in accordance with the applicable financial reporting framework or as Modified opinion (an qualified opinion, an adverse opinion or a disclaimer of opinion on the financial statements) when the auditor concludes that, based on the audit evidence obtained, the financial statements as a whole are not free from material misstatement or the auditor is unable to obtain sufficient appropriate audit evidence to conclude that the financial statements as a whole are free from material misstatement [1].

The Public sector auditing provides transparency, accountability and value for money and results in good governance [2]. In Local Government there are several areas that should be object of external audit due to the special interest of the recipients and users of the audit reports.
Evaluating the efforts undertaken to obtain a more rigorous and transparent public management, several studies focus their attention on the practices of accountability, transparency and reliability of the information produced and disseminated by the municipalities. However, in Portugal, the external auditing of the local public sector is relatively recent and was only introduced in 2007 for some municipalities, and its scope was extended to all municipalities in 2013 with the new Financial Regime of Local Government and Intermunicipal Entities.

Several studies have been carried out for the private sector, trying to identify the factors that determine modified opinions, however, as regards local entities, the theme is not so developed in Portugal due to the recent mandatory external audit. The objective of the paper is to identify the factors that determine auditors modified opinions in Portuguese local government entities.

In addition to this introduction of the theme, this article presents in chapter 2 a brief literature review and in chapter 3 are presented the data and methodology. Chapter 4 summarizes the main results and chapter 5 concludes.

\section{LITERATURE REVIEW}

Having an independent auditor is one of the best ways of getting an objective and unbiased opinion on something [3]. According to [4], the role of the audit in government tends to follow changes in demands on the public sector which are determined by regulatory changes that allow the audit role adjusted to adapt to changes in public management. Thus, the public sector auditing provides transparency, accountability and value for money and results in good governance [2]. [5] state that "audit reports are a key element for auditors to promote accountability and clear criteria in the form of professional audit standards to assist in producing credible reports on government performance that provide focus, transparency, and predictability".

In Portugal, until 2007, local authorities auditing was carried out by the Court of Auditors, by the General inspection of finances and by the General inspection of the local administration. Within the objectives of the so-called new public 
management and seeking to prevent bad management practices and provide municipal accounts with greater transparency, the Portuguese government reinforced the role of auditing with the approval of the Portuguese Law of Local Finances (Law n. ${ }^{\circ}$ 2/2007, of January 15). The Portuguese Law of Local Finances of 2007 stated that municipalities that have capital in foundations or local business sector entities were obliged to have their accounts audited and issued the respective Legal Certification of Accounts by an external auditor.

In 2013, the new Local Finance Law (Law n. ${ }^{\circ} 73 / 2013$, of September 03) repealed the Law n. ${ }^{\circ} 2 / 2007$ and expanded the range of local authorities' subject to external audit to all municipalities that have full accounting system.

In accounting terms, local authorities and similar entities apply the Local Authorities Official Plan of Accounting (POCAL) approved by Decree-Law n. ${ }^{\circ}$ 54-A 99, of February 22. The POCAL must be applied to all local authorities and similar entities, namely metropolitan areas, district assemblies, associations and municipalities under public law, as well as entities which, by law, are subject to the accounting system of local authorities.

The local authorities accounts include: Balance sheet, Income statement, Budget execution maps (Budget control map, Cash flow map, Treasury operations map), financial statements annex and Management report.

In accordance with article n. ${ }^{\circ} 77$ of the Law n. ${ }^{\circ} 73 / 2013$, it is the responsibility of the external auditor matters such as:

- verify the regularity of the books, accounting records and documents that support them;

- participate irregularities to the responsible municipalities as well as facts that considers to be serious difficulties in the pursuit of the municipality's multiannual investment plan;

- verify the municipality assets; send every six months to the entity's executive and deliberative bodies information on the economic and financial situation;

- and to issue an opinion on the accounting documents for the financial year, in particular on the budget execution, the balance sheet and the individual and consolidated income statement and annexed documents.

In the case of municipalities, the legal certification of individual accounts includes municipal services, although it may be carried out in autonomous terms following the municipal assembly's resolution, on proposal of the municipal council.

This situation may also apply to inter-municipal services. It is also responsibility of upon the external auditor to decide on any other situations determined by law, in particular on financial recovery plans.

According to [1], the auditor objective "is to identify and to assess the risks of material misstatement, whether due to fraud or error, at the financial statement and assertion levels, through understanding the entity and its environment, including the entity's internal control, thereby providing a basis for designing and implementing responses to the assessed risks of material misstatements".

We can find several studies trying to identify the factors that determine modified opinions in private sector companies, establishing its relation to the assertions associated with classes of transactions, account balances and related disclosures and assertions associated with other disclosures ([6], [7], [8], [9]).

In contrast to the private sector, with respect to the Legal Certification of Accounts issued by external auditors of local government entities, few studies are found to identify which factors determine a change in the auditor's opinion.

According to [10], research in the private sector revealed several determinants including audit report lag, size, leverage, profitability, audit fees, auditor independence, auditor tenure, and the size of the audit firm, but the issue remains neglected in the case of municipalities and other municipal organizations. In line with private sector studies, [10] paper explores the determinants of modified audit reports among joint municipal authorities in Finland finding that a long audit report lag, audit firm size and a large organizational size seem to increase the likelihood of a modified audit opinion, whereas high leverage, a large organizational size and the male gender of the principal auditor increase the likelihood of modified results of the audit.

Analyzing the question from a different point of view, [11] finds that the deficiency in the internal control system, the noncompliance with regulations and laws and the nonconformance with the Government Accounting Standards have been significantly affecting audit opinion of municipal government financial statements in Indonesia.

Based on the analysis of the Legal Certification of Accounts issued by external auditors of local government entities, our goal is to identify the factors that determine auditors modified opinions in Portuguese municipalities. Reasons given by auditors for the modified opinion will be analyzed, seeking to establish the factors that justify the existence of distortions in the information provided by the municipalities. We will also seek to verify if there are audit assertion frequently used to justify the opinion modification and if it is possible associate them to equity or results accounts.

\section{DATA AND Methodology}

For this study were collected Legal Certification of Accounts on individual accounts issued by external auditors of Portuguese municipalities that integrate the metropolitan areas of Porto (AMP) and Lisbon (AML). The defined time horizon was from 2013, year of introduction of Law n. ${ }^{\circ} 73 / 2013$, to 2017 , last year available.

With reference to 2017, the 65 municipalities that integrate the metropolitan areas accounted for approximately $40,7 \%$ of revenues and $38,2 \%$ of the expenses of Portuguese municipalities, comprising $44,1 \%$ of the Portuguese population. 
TABLE I. EXPENSES OF PORTUGUESE METROPOLITAN AREAS, CONTINENT, AND AUTONOMOUS REGIONS

\begin{tabular}{|c|c|c|c|c|c|}
\hline $\begin{array}{c}\text { Euro - } \\
\text { Thousands }\end{array}$ & 2013 & 2014 & 2015 & 2016 & 2017 \\
\hline $\begin{array}{c}\text { Porto } \\
\text { metropolitan } \\
\text { area }\end{array}$ & 983787 & 801006 & 813180 & 851283 & 903848 \\
\hline $\begin{array}{c}\text { Lisbon } \\
\text { metropolitan } \\
\text { area } \\
\end{array}$ & 1568553 & 1615751 & 1603263 & 1762503 & 1876633 \\
\hline Continent & 6723681 & 6207429 & 6218643 & 6379728 & 6952918 \\
\hline $\begin{array}{c}\text { Azores } \\
\text { autonomous } \\
\text { region }\end{array}$ & 158769 & 155691 & 149360 & 144416 & 162624 \\
\hline $\begin{array}{c}\text { Madeira } \\
\text { autonomous } \\
\text { region }\end{array}$ & 194376 & 157785 & 136129 & 137274 & 157001 \\
\hline
\end{tabular}

The external auditor reports collection was done through the municipalities web pages and it was possible to obtain 101 reports. Of the 35 municipalities analyzed, 6 had no Legal Certification of Accounts available for the period under analysis, belonging 4 to AMP and 2 to AML.

For the remaining 29 municipalities, 8 had information for the entire period under review, 10 for only four economic years, 2 municipalities for three, 6 for two years and 3 for only one year (Appendix - Tables A and B).

Following a content analysis methodology, a previous analysis of the collected 101 audit reports was performed and we identified 65 audit reports with a modified opinion (M) and 36 with an unmodified opinion (U). Table II and Table III present the results for municipalities organized for the two metropolitan areas of Porto and Lisbon.

The bases for the opinion issue presented in the 65 reports with modified opinion were analyzed, trying to identify the nature of the opinion modification and its relation with audit assertions and also regarding their effect on equity and/or results accounts.

TABLE II. OPINION IN LEGAL CERTIFICATION OF ACCOUNTS - AMP

\begin{tabular}{|l|c|c|c|c|c|}
\cline { 2 - 6 } \multicolumn{1}{c|}{} & 2017 & 2016 & 2015 & 2014 & 2013 \\
\hline \multicolumn{1}{c|}{ AMP: } & & & & & \\
Arouca & -- & --- & --- & --- & --- \\
Espinho & $\mathrm{M}$ & $\mathrm{M}$ & $\mathrm{M}$ & $\mathrm{M}$ & --- \\
Gondomar & $\mathrm{M}$ & $\mathrm{M}$ & $\mathrm{M}$ & $\mathrm{M}$ & $\mathrm{M}$ \\
Maia & $\mathrm{U}$ & $\mathrm{U}$ & $\mathrm{U}$ & $\mathrm{U}$ & $\mathrm{U}$ \\
Matosinhos & $\mathrm{U}$ & $\mathrm{U}$ & $\mathrm{U}$ & $\mathrm{U}$ & $\mathrm{U}$ \\
Oliveira de Azeméis & --- & --- & --- & --- & --- \\
Paredes & --- & --- & -- & --- & --- \\
Porto & $\mathrm{M}$ & $\mathrm{M}$ & $\mathrm{M}$ & $\mathrm{M}$ & $\mathrm{M}$ \\
Póvoa de Varzim & $\mathrm{U}$ & $\mathrm{U}$ & $\mathrm{U}$ & $\mathrm{U}$ & $\mathrm{U}$ \\
Santa Maria da Feira & $\mathrm{U}$ & $\mathrm{U}$ & $\mathrm{U}$ & $\mathrm{U}$ & --- \\
Santo Tirso & $\mathrm{M}$ & --- & --- & --- & --- \\
São João da Madeira & --- & --- & --- & --- & --- \\
Trofa & --- & $\mathrm{M}$ & $\mathrm{M}$ & $\mathrm{M}$ & $\mathrm{M}$ \\
Vale de Cambra & --- & --- & $\mathrm{M}$ & $\mathrm{M}$ & --- \\
Valongo & $\mathrm{M}$ & $\mathrm{M}$ & $\mathrm{M}$ & $\mathrm{M}$ & --- \\
Vila do Conde & $\mathrm{M}$ & $\mathrm{M}$ & $\mathrm{M}$ & $\mathrm{U}$ & ---
\end{tabular}

\begin{tabular}{|c|c|c|c|c|c|} 
Vila Nova de Gaia & M & M & M & --- & --- \\
\hline M - AMP & 7 & 7 & 8 & 6 & 3 \\
\hline U - AMP & 4 & 4 & 4 & 5 & 3 \\
\hline
\end{tabular}

TABLE III. OPINION IN LEGAL CERTIFICATION OF ACCOUNTS - AML

\begin{tabular}{|c|c|c|c|c|c|}
\hline & 2017 & 2016 & 2015 & 2014 & 2013 \\
\hline AML: & & & & & \\
\hline Alcochete & $\mathrm{U}$ & --- & --- & --- & --- \\
\hline Almada & M & M & M & M & --- \\
\hline Amadora & M & M & --- & --- & --- \\
\hline Barreiro & M & M & M & M & --- \\
\hline Cascais & $\mathrm{U}$ & M & M & M & --- \\
\hline Lisboa & $\mathrm{U}$ & $\mathrm{U}$ & M & M & M \\
\hline Loures & M & M & M & M & --- \\
\hline Mafra & M & M & M & M & M \\
\hline Moita & $\mathrm{U}$ & $\mathrm{U}$ & $\mathrm{U}$ & $\mathrm{U}$ & $\mathrm{U}$ \\
\hline Montijo & M & M & M & --- & --- \\
\hline Odivelas & $\mathrm{U}$ & $\mathrm{U}$ & --- & --- & --- \\
\hline Oeiras & M & --- & --- & --- & --- \\
\hline Palmela & --- & --- & --- & --- & --- \\
\hline Seixal & M & M & --- & --- & --- \\
\hline Sesimbra & --- & --- & --- & --- & --- \\
\hline Setúbal & --- & --- & U & U & --- \\
\hline Sintra & $\mathrm{U}$ & $\mathrm{U}$ & --- & --- & --- \\
\hline Vila Franca de Xira & --- & U & M & M & $\mathrm{M}$ \\
\hline $\mathrm{M}-\mathrm{AML}$ & 8 & 8 & 8 & 7 & 3 \\
\hline $\mathrm{U}-\mathrm{AML}$ & 6 & 5 & 2 & 2 & 1 \\
\hline
\end{tabular}

\section{RESUlTS}

The modified opinions collected in the available reports allowed us to identify eleven recurrent factors related with: noncurrent assets, amortizations, subsidies - investment, equity investments, inventories, debts to receive, impairments, debts to pay, provisions, cost accounting system and internal control (figure 1). The factors found are in line with the conclusions of [11], which also highlight non-compliance with accounting standards and deficiencies in internal control as factors with a significant impact on changing the auditor's opinion. 


\section{Determinants of modified opinion}

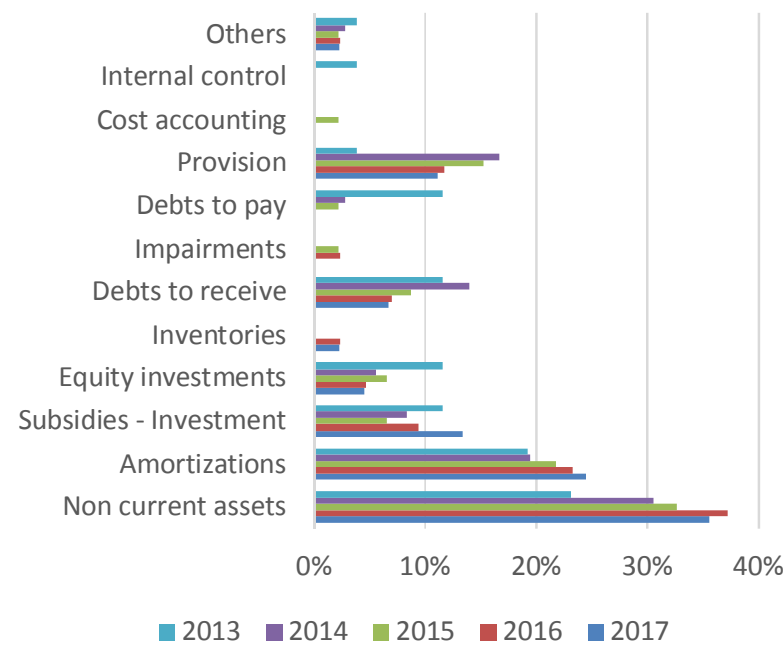

Figure 1. Determinants of auditor modified opinion.

From these eleven factors, we will highlight the six predominant factors in the last years, namely non-current assets, amortizations, subsidies - investment, debts to receive, impairments, debts to pay, equity investments and provisions.

The POCAL adoption in 2002 impose to local entities the obligation to present accounting documents reflecting the financial, economic and patrimonial activity.

Among the main consequences was the need to inventory all assets and to recognize and value all the items included in local entities assets: tangible fixed assets, intangible fixed assets, assets in progress, public domain assets. However, as presented in table IV, one of the main causes for the change of opinion identified refers to non-current fixed assets, reaching a weight of $36 \%$ in 2017.

TABLE IV. MODIFIED OPINION - NON-CURRENT ASSETS

\begin{tabular}{|l|r|r|r|r|r|}
\hline & 2017 & 2016 & 2015 & 2014 & 2013 \\
\hline Non-current fixed assets & $36 \%$ & $37 \%$ & $33 \%$ & $31 \%$ & $23 \%$ \\
\hline
\end{tabular}

[12] highlights as areas of high material distortion risk in municipalities: fixed assets, depreciation and subsidies to investments, mainly due to the existence unidentified/ unregistered properties, incorrect initial assets inventory, incorrect transfers or lack of transfer to fixed assets of assets in progress, impacts in assets amortizations and problems regarding the asset's ownership.

Still, in 2017 we find the same problems. Fifteen years after POCAL adoption, problems regarding non-current assets identification, classification, measurement and registration represents approximately one-third of reasons to modified opinions.

According to [12], these situations often result in the need for more analytical review procedures, substantive procedures (acquisitions, donations, transfers, amortizations), proof of ownership, physical verification of assets, external confirmation with fixed asset suppliers and financing entities, among others.

Consequently, the difficulties for the external auditor in the validation of assertions referring not only to the several fixed assets items but also in the corresponding amortization (year and accumulated), deferred income associated with the investment subsidies and effects on the period result, lead to the inability to obtain sufficient appropriated audit evidence (table V).

TABLE V. MODIFIED OPINION - AMORTIZATIONS AND INVESTMENT SUBSIDIES

\begin{tabular}{|c|r|r|r|r|r|}
\hline & 2017 & 2016 & 2015 & 2014 & 2013 \\
\hline Amortizations & $24 \%$ & $23 \%$ & $22 \%$ & $19 \%$ & $19 \%$ \\
\hline Investment subsidies & $13 \%$ & $9 \%$ & $7 \%$ & $8 \%$ & $12 \%$ \\
\hline
\end{tabular}

For this reason, there are recurring statements that it is not possible to express an opinion on the completeness and adequacy of the value of this asset item, as well as respective amortizations, subsidies for investment and effects on net result.

Being a provision the amount of an expense that an entity elects to recognize now, before it has precise information about the exact amount of the expense, it should be recognized as an expense when the occurrence of the related obligation is probable, and one can reasonably estimate the amount of the expense. However, as presented in table VI, not always these are correctly reported.

There are several modified opinions relative to lawsuits provisions regarding the lack of information to quantify and validate it's future impact. We also find reasons related to the insufficiency of the value provisioned by the municipalities leading to undervalued liabilities and overvalued equity and net result.

TABLE VI. MODIFIED OPINION - PROVISIONS

\begin{tabular}{|r|r|r|r|r|r|}
\hline & 2017 & 2016 & 2015 & 2014 & 2013 \\
\hline Provisions & $11 \%$ & $12 \%$ & $15 \%$ & $17 \%$ & $4 \%$ \\
\hline
\end{tabular}

As regards the acquisition and holding of interests in local business entities (municipal or intermunicipal services) (table VII) by the municipalities, the most frequently questions concern the equity method application.

The measurement of Investments is indicated by [12] as an area of median material distortion risk in municipalities, and it is necessary to analyze the impact of non-adoption of the equity method and possible overvaluation of financial investments.

The equity method is a method of accounting whereby the investment is initially recognized at cost and subsequently adjusted for changes in the investor's share of the net assets of the investee after acquisition. The investor's results also include the part that corresponds to it in the results of the investee.

TABLE VII. MODIFIED OPINION - EQUITY INVESTMENTS 


\begin{tabular}{|l|r|r|r|r|r|} 
Equity investments & $4 \%$ & $5 \%$ & $7 \%$ & $6 \%$ & $12 \%$ \\
\hline
\end{tabular}

Elaborated by the authors.

The recurrent basis for the modified opinion is that the investee has not yet audited accounts and therefore it is not possible to assess the need for capital adjustments and also impact on municipality equity of non-application of the equity method to significant participations

Regarding the Debts to receive (table VIII), a key factor in modified opinions the is the lack of response to the circulations made.

TABLE VIII. MODIFIED OPINION - DEBTS TO RECEIVE

\begin{tabular}{|l|r|r|r|r|r|}
\hline & 2017 & 2016 & 2015 & 2014 & 2013 \\
\hline Debts to receive & $7 \%$ & $7 \%$ & $9 \%$ & $14 \%$ & $12 \%$ \\
\hline
\end{tabular}

An external confirmation represents audit evidence obtained by the auditor as a direct written response to the auditor from a third party in paper from or by electronic or other medium [1]. Being material, lack of external confirmation leads lead to the inability to obtain sufficient appropriated audit evidence.

\section{CONCLUSIONS}

This paper examined the determinants of modified audit opinions reports in Portuguese metropolitan areas of Porto and Lisbon from 2013 to 2017. Our goal was to determine the main reasons given by auditors for the modified opinion and identify the items that are the primary cause of distortions in the information provided by the municipalities.

Following a content analysis methodology, we identified 65 audit reports with modified opinion and six predominant factors related with: non-current assets, amortizations, subsidies to investments, debts to receive, equity investments and provisions, associated with the non-compliance with accounting standards as in [11].

The analysis allows to highlight the fact that approximately one-third of reasons to modified opinions are related to problems in audit assertions on fixed assets.

This suggests the greater probability of material distortions associated with the measurement of non-current assets, especially fixed assets, which can be explained by the difficulty faced by municipalities in identification, classification, measurement and assets registration.

\section{REFERENCES}

[1] IFAC (2018). Handbook of International Quality Control, Auditing, Review, Other Assurance, and Related Services Pronouncements. 2018 edition. The International Federation of Accountants (IFAC)

[2] Curtin D. and Dekker I. (2005). Good governance: The concept and its application by the European Union. In: Curtin D and Wessel R (eds) Good Governance and the European Union: Reflections on Concepts, Institutions and Substance. New York: Intersentia.

[3] Moroney, R., Campbell, F. and Hamilton, J. (2014). Auditing: A Practical Approach, 2nd ed., Wiley, Milton.

[4] Pearson, D. (2014). Significant reforms in public sector audit - Staying relevant in times of change and challenge. Journal of Accounting and Organizational Change, 10(1), 150-161.
[5] Rosa C. P., and Morote R.P. (2016). The audit report as an instrument for accountability in local governments: A proposal for Spanish municipalities, International Review of Administrative Sciences, 82(3).

[6] Costa, R., Serra, S. and Gomes, P. (2013). Fatores determinantes da opinião do auditor: estudo empírico das empresas portuguesas. Proceedings of XVI Congresso Internacional Contabilidade e Auditoria, Aveiro.

[7] Carson, E., Fargher, N. L., Geiger, M. A. and Lennox, C. S. (2013). ‘Audit reporting for going-concern uncertainty: a research synthesis, Auditing: A Journal of Practice \& Theory, Vol. 32, Supplement 1, pp. 353-84.

[8] Habib, A. (2013). A meta-analysis of the determinants of modified audit opinion decisions, Managerial Auditing Journal, Vol. 28, No. 3, pp. 184 216.

[9] Silva, T., and Dantas, J. (2018). Audit Assertions e a Modificação de Opinião dos Auditores no Mercado Brasileiro. Revista de Educação e Pesquisa em Contabilidade (REPeC), 12(1).

[10] Paananen, M. (2016). Modified Audit Reports I the Case of Joint Authorities: Empirical Evidence from Finland. International Journal of Auditing, 20 (2), 149-157.

[11] Pamungkas, B., Ibtida, R., and Avrian, C. (2018). Factors Influencing Audit Opinion of the Indonesian Municipal Governments' Financial Statements. Cogent Business \& Management, 5(1), 1-18.

[12] Moura, N. (2011). Procedimentos de auditoria a adoptar na revisão legal das contas dos municípios: Enquadramento teórico e aplicação prática. Revisores \& Auditores, 52, 22-34.

\section{APPENDIX}

TABle A Municipalities With Legal Certification OF ACCOUNTS AVAILABLE - AMP

\begin{tabular}{|c|c|c|c|c|c|c|}
\hline AMP & 2017 & 2016 & 2015 & 2014 & 2013 & Total \\
\hline Arouca & 0 & 0 & 0 & 0 & 0 & 0 \\
Espinho & 1 & 1 & 1 & 1 & 0 & 4 \\
Gondomar & 1 & 1 & 1 & 1 & 1 & 5 \\
Maia & 1 & 1 & 1 & 1 & 1 & 5 \\
Matosinhos & 1 & 1 & 1 & 1 & 1 & 5 \\
Oliveira de Azeméis & 0 & 0 & 0 & 0 & 0 & 0 \\
Paredes & 0 & 0 & 0 & 0 & 0 & 0 \\
Porto & 1 & 1 & 1 & 1 & 1 & 5 \\
Póvoa de Varzim & 1 & 1 & 1 & 1 & 1 & 5 \\
Santa Maria da & 1 & 1 & 1 & 1 & 0 & 4 \\
Feira & 1 & 0 & 0 & 0 & 0 & 1 \\
Santo Tirso & 0 & 0 & 0 & 0 & 0 & 0 \\
São João da & 0 & 1 & 1 & 1 & 1 & 4 \\
Madeira & 0 & 0 & 1 & 1 & 0 & 2 \\
Trofa & 1 & 1 & 1 & 1 & 0 & 4 \\
Vale de Cambra & 1 & 1 & 1 & 1 & 0 & 4 \\
Valongo & 1 & 1 & 1 & 0 & 0 & 3 \\
Vila do Conde & 11 & 11 & 12 & 11 & 6 & 51 \\
Vila Nova de Gaia & & & Elaborated by the authors. \\
\multicolumn{2}{|c|}{} & &
\end{tabular}

Table B Municipalities With Legal Certification of ACCOUNTS AVAILABLE - AML

$$
\begin{array}{|l|l|l|l|l|l|l|}
\hline \text { AML } & 2017 & 2016 & 2015 & 2014 & 2013 & \text { Total } \\
\hline
\end{array}
$$




\begin{tabular}{|c|c|c|c|c|c|c|}
\hline Alcochete & 1 & 0 & 0 & 0 & 0 & 1 \\
Almada & 1 & 1 & 1 & 1 & 0 & 4 \\
Amadora & 1 & 1 & 0 & 0 & 0 & 2 \\
Barreiro & 1 & 1 & 1 & 1 & 0 & 4 \\
Cascais & 1 & 1 & 1 & 1 & 0 & 4 \\
Lisboa & 1 & 1 & 1 & 1 & 1 & 5 \\
Loures & 1 & 1 & 1 & 1 & 0 & 4 \\
Mafra & 1 & 1 & 1 & 1 & 1 & 5 \\
Moita & 1 & 1 & 1 & 1 & 1 & 5 \\
Montijo & 1 & 1 & 1 & 0 & 0 & 3 \\
Odivelas & 1 & 1 & 0 & 0 & 0 & 2 \\
Oeiras & 1 & 0 & 0 & 0 & 0 & 1 \\
Palmela & 0 & 0 & 0 & 0 & 0 & 0 \\
Seixal & 1 & 1 & 0 & 0 & 0 & 2 \\
Sesimbra & 0 & 0 & 0 & 0 & 0 & 0 \\
Setúbal & 0 & 0 & 1 & 1 & 0 & 2 \\
Sintra & 1 & 1 & 0 & 0 & 0 & 2 \\
Vila Franca de Xira & 0 & 1 & 1 & 1 & 1 & 4 \\
\hline & 14 & 13 & 10 & 9 & 4 & 50 \\
\hline
\end{tabular}

